Journal of Telenursing (JOTING)

Volume 1, Nomor 1, Juni 2019

e-ISSN : 2684-8988

p-ISSN : 2684-8996

DOI: https://doi.org/10.31539/joting.v1i1.516

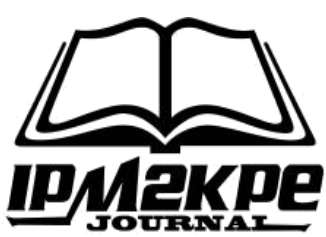

\title{
PERBEDAAN TEKANAN DARAH SEBELUM DAN SESUDAH PEKERJA TERPAJAN KEBISINGAN DI PENGGILINGAN PADI DAN KOPI
}

\author{
Muhammad Amin ${ }^{1}$, Rita Rosari ${ }^{2}$, Yenida $^{3}$ \\ Program Studi Kesehatan Masyarakat, Universitas Muhammadiyah Bengkulu ${ }^{1,2,3}$ \\ Email. Amuh638@gmail.com
}

\begin{abstract}
ABSTRAK
Penelitian ini bertujuan untuk mengetahui perbedaan tekanan darah sebelum dan sesudah pekerja terpajan kebisingan di penggilingan padi dan kopi Kabupaten Kepahiang. Jenis penelitian kuantitatif dan rancangan penelitian yang digunakan pre experimental design dengan pendekatan one group pretest posttest. Teknik pengambilan sampel yang digunakan adalah total sampling dengan jumlah sampel 22 pekerja titik 1 mengalami kenaikan tekanan darah sistole (39.29\%) dan 17 pekerja titik 2 tidak mengalami kenaikan tekanan darah Sistole (30.36\%). Sedangkan untuk tekanan darah diastole, sebanyak 14 pekerja titik 1 mengalami kenaikan tekanan darah diastole (25\%) dan 18 pekerja titik 2 tidak mengalami kenaikan tekanan darah diastole (30\%). Berdasarkan hasil uji statistik Wil Coxon Signed Ranks Test didapatkan nilai $\mathrm{p}=0.000<$ $\alpha(0.05)$ untuk tekanan darah sistole pekerja titik $1, \mathrm{p}=0.000<\alpha(0.05)$ untuk tekanan darah sistole pekerja titik $2, \mathrm{p}=0.000<\alpha(0.05)$ untuk tekanan darah diastole pekerja titik 2 , dan $\mathrm{p}=0.002<\alpha(0.05)$ untuk tekanan darah diastole pekerja titik 2. Sehingga terdapat perbedaan yang bermakna tekanan darah sebelum dan sesudah pekerja terpajan kebisingan di penggilingan padi dan kopi Kabupaten Kepahiang.
\end{abstract}

Kata Kunci : Kebisingan, Tekanan darah

\section{ABSTRACT}

This study aims to determine differences in blood pressure before and after workers exposed to noise in rice and coffee milling in Kepahiang Regency. This research was conducted in July 2017 with quantitative research type and research design which used pre experimental design with one group pretest posttest approach. The sampling technique used is total sampling with sample is 22 workers at point 1 had increased sistole blood pressure (39.29\%) and 17 workers at point 2 did not increase Sistole blood pressure (30.36\%). While for diastolic blood pressure, there were 14 workers at point 1 had an increase in diastolic blood pressure (25\%) and 18 workers point 2 did not increase diastolic blood pressure (30\%). Based on Wil Coxon Signed Ranks Test statistical results obtained $p=0.000<\alpha(0.05)$ for blood pressure of laborer systole point $1, p=0.000<\alpha(0.05)$ for blood pressure sistole worker point $2, p=0.000<\alpha$ (0.05) for diastolic blood pressure point 2 , and $p=0.002<\alpha(0.05)$ for the worker's diastolic blood pressure at point 2. So there is a significant difference in blood pressure before and after workers exposed to noise in rice and coffee milling in Kepahiang Regency.

Keywords: Blood Pressure, Noisy 


\section{PENDAHULUAN}

Perkembangan pembangunan industri di Indonesia telah mengalami kemajuan yang sangat pesat. Dalam pembangunan di Indonesia, Industri akan terus berkembang sampai tingkat industri maju. Seperti diketahui bahwa hampir semua jenis industri mempergunakan mesin-mesin yang dapat menjadikan sumber kebisingan. Selanjutnya dapat dimengerti bahwa dengan berkembang nya industri di Indonesia maka akan semakin besarlah jumlah tenaga kerja dalam pekerjanya yang selalu terpapar pada intensitas bising yang tinggi dan berlangsung lama. Oleh karena itu sebaiknya kesehatan kerja mendapatkan perhatian lebih banyak bagi kalangan kesehatan. Perlindungan tenaga kerja meliputi aspek yang cukup luas yaitu perlindungan keselamatan, kesehatan, pemeliharaan moral kerja serta perlakuan yang sesuai dengan martabat dan moral bangsa (Budiono, 2003).

Setiap pekerjaan memiliki potensi bahaya (hazard) yang dapat menimbul-kan kecelakaan atau penyakit akibat kerja.Salah satu potensi bahaya yang terdapat di lingkungan kerja adalah kebisingan. Kebisingan merupakan polusi ketiga tertinggi di kota-kota besar (Zamanian dkk, 2013). Setiap hari terdapat 4 juta pekerja dalam bahaya kebisingan, sedangkan setiap tahunnya 22 juta pekerja berpotensi terpapar bahaya kebisingan (NIOSH, 2015). Industri di Amerika Serikat membayar denda lebih dari 1,5 juta dolar akibat tidak melindungi para pekerja dari kebisingan (OSHA, 2016). WHO juga melaporkan bahwa kebisingan menyebabkan kerugian kesehatan sebesar 4 juta dolar setiap harinya dan menempat-kan pekerja pada risiko kesehatan yang tinggi (Zamanian dkk, 2013).

Kebisingan dalam kesehatan kerja dapat diartikan sebagai suara yang dapat menurunkan pendengaran baik secara kuantitatif (peningkatan ambang pendengaran) maupun secara kualitatif (penyempitan spektrum pendengaran), berkaitan dengan faktor intensitas, frekuensi, durasi dan pola (Depkes, 2009).

Paparan kebisingan tidak hanya menyebabkan gangguan yang bersifat pendengaran (auditory) namun juga menyebabkan gangguan yang bersifat non pendengaran (non-auditory) (Jumali dkk,2013). Gangguan yang bersifat pendengaran adalah tinnitus atau telinga berdengung, kesulitan membedakan kata dengan frekuensi tinggi (Jumali dkk, 2013:545-546) dan dampak yang paling serius yang dapat terjadi adalah ketulian atau NIHL (Noise Induced Hearing Loss) pada pekerja yang terpapar kebisingan level tinggi. Sementara gangguan non-auditory yang dapat terjadi akibat paparan kebisingan adalah gangguan tidur, gangguan sistem kardiovaskular, dan penurunan daya kognitif anak (Basner dkk, 2014). Salah satu hasil penelitian melaporkan kebisingan merupakan penyebab ketiga dari serangan jantung pada penduduk di Berlin setelah rokok dan polusi udara (Zamanian dkk, 2013).

Kebisingan merupakan stressor yang berhubungan dengan sistem hormon dan respon kardiovaskular yang dalam jangka panjang dapat menyebabkan hipertensi dan penyakit kardiovaskular (Foraster dkk, 2014). Penyakit pada sistem kardiovaskular merupakan salah satu penyebab utama kematian (Souza dkk, 2015). Salah satu penyakit pada sistem kardiovaskular adalah hipertensi atau terjadinya peningkatan tekanan darah. Secara global angka kejadian hipertensi diperkirakan mencapai 30\% dari total populasi dan merupakan penyebab kematian sebesar 7,1 juta jiwa per tahun (Mortimer 2011; Andri, 2018).

Berdasarkan Keputusan Menteri Tenaga Kerja No. 13/Men/2011, Nilai Ambang Batas (NAB) kebisingan adalah sebesar $85 \mathrm{~dB}$ dengan waktu pajanan tidak boleh bekerja lebih dari 8 jam sehari. Kebisingan menimbulkan beberapa dampak kesehatan. 
Selain berdampak terhadap gangguan pendengaran intensitas bising yang tinggi juga dapat mengakibatkan hilangnya konsentrasi, hilangnya keseimbangan dan disorientasi, kelelahan, gangguan komunikasi, gangguan tidur, gangguan pelaksanaan tugas, gangguan faal tubuh, serta adanya efek visual, seperti perubahan frekuensi jantung/peningkatan denyut nadi, perubahan tekanan darah dan tingkat pengeluaran keringat (Harrington \& Gill, 2003).

Kebisingan bisa direspon oleh otak yang merasakan pengalaman ini sebagai ancaman stress. Stress akan mempengaruhi sistem saraf yang kemudian berpengaruh pada denyutan jantung yang mengakibatkan perubahan tekanan darah. Stress yang berulang-ulang bisa menjadikan perubahan tekanan darah itu menetap (Jenni, 2007). Hasil analisis statistik yang dilakukan oleh Eny Hastuti, et. al (2005) menunjukkan adanya hubungan bermakna antara intensitas kebisingan dengan kenaikan tekanan darah sistolik.

Kabupaten Kepahiang adalah kabupaten yang terdapat di Provinsi Bengkulu. Secara administratif daerah ini terbagi menjadi 8 kecamatan dan 91 desa. Pada setiap kecamatan terdapat beberapa usaha penggilingan padi. Dari 8 kecamatan terdapat 4 kecamatan (Kecamatan Kepahiang, Kecamatan Seberang Musi, Kecamatan Taba Karai, Kecamatan Kabawetan) yang memiliki usaha penggilingan padi dengan waktu bekerja selama 8 jam perhari (terkadang lembur). 4 kecamatan lainnya (Kecamatan Bermani Ilir, Kecamatan Ujan Mas, Kecamatan Muara Kemumu, Kecamatan Merigi) hanya mengoperasikan usaha penggilingan padi pada waktu tertentu (tergantung waktu panen).

Usaha penggilingan padi dalam kegiatan produksinya menggunakan mesin-mesin kerja yang menimbulkan kebisingan. Pada survey awal yang peneliti lakukan, 4 kecamatan yang memiliki waktu bekerja selama 8 jam perhari (terkadang lembur) ternyata tidak hanya menerima permintaan penggilingan padi saja, tetapi juga kopi, sehingga mesin tetap selalu beroperasi setiap harinya. Pada survey yang peneliti lakukan di salah satu usaha penggilingan padi di desa Kampung Bogor Kabupaten Kepahiang, diketahui bahwa pekerja belum mengetahui tentang keselamatan dan kesehatan kerja. Berdasarkan pengukuran intensitas kebisingan mesin penggilingan padi didapatkan hasil sebesar 91,06 dB dan pekerja bekerja selama 8 jam perhari (terkadang lembur).

\section{METODE PENELITIAN}

Penelitian ini merupakan penelitian kuantitatif dengan menggunakan jenis penelitian pre experimental design dengan pendekatan one group pretest posttest. Penelitian ini dilaksanakan pada Juli 2017 dengan wilayah penelitian 4 Kecamatan di Kabupaten Kepahiang terdiri dari Kecamatan Kepahiang, Kecamatan Seberang Musi, Kecamatan Taba Karai, dan Kecamatan Kabawetan.

Teknik pengambilan sampel yang digunakan adalah total sampling dengan kriteria sampel adalah responden yang melakukan pekerjaannya pada saat dilakukan penelitian, bekerja $\geq 2$ jam, berjenis kelamin laki-laki serta bersedia menjadi responden, sedangkan pekerja yang menggunakan APT (Alat Pelindung Telinga) tidak dimasukkan kedalam penelitian. Sehinga sampel yang digunakan dalam penelitian ini adalah seluruh pekerja penggilingan padi dan kopi yang berjumlah 56 pekerja terdiri dari 28 pekerja bagian bawah (titik 1) dan 28 pekerja bagian atas (titik 2).

Instrumen yang digunakan dalam penelitian ini adalah alat pengukur kebisingan berupa Sound Level Meter dan alat pengukur tekanan darah berupa tensimeter aneroid. Menggunakan data primer dan sekunder dengan analisa data menggunakan uji Wilcoxon Signed Ranks Test. 
HASIL PENELITIAN

Analisis Univariat

Tabel 1

Hasil Pengukuran Intensitas Kebisingan di 22 Lokasi Penggilingan Padi dan Kopi

\begin{tabular}{|c|c|c|c|}
\hline \multirow{2}{*}{ No. } & \multirow{2}{*}{ Lokasi } & \multicolumn{2}{|c|}{ Leq $($ Level Euipvalent $)=$ Tingkat Kebisingan $(\mathrm{dB})$} \\
\hline & & Titik 1 & Titik 2 \\
\hline \multicolumn{4}{|c|}{ I. Kecamatan Taba Karai } \\
\hline 1. & Taba Sating I & 91,4 & 85,1 \\
\hline 2. & Taba Sating II & 92,0 & 85,1 \\
\hline 3. & Penanjung & 92,4 & 85,3 \\
\hline 4. & Tertik I & 92,4 & 85,8 \\
\hline 5. & Tertik II & 92,7 & 84,5 \\
\hline 6. & Tertik III & 92,3 & 85,0 \\
\hline \multicolumn{4}{|c|}{ II. Kecamatan Kabawetan } \\
\hline 1. & Tangsi Duren & 93,5 & 86,2 \\
\hline \multicolumn{4}{|c|}{ III. Kecamatan Kepahiang } \\
\hline 1. & Tebat Monok I & 93,3 & 85,4 \\
\hline 2. & Tebat Monok II & 91,8 & 84,6 \\
\hline 3. & Tebat Monok III & 93,3 & 85,3 \\
\hline 4. & Tebat Monok IV & 93,4 & 83,6 \\
\hline 5. & Kampung Bogor I & 90,7 & 85,1 \\
\hline 6. & Kampung Bogor II & 90,8 & 84,6 \\
\hline \multicolumn{4}{|c|}{ IV. Kecamatan Seberang Musi } \\
\hline 1. & Cirebon Baru I & 91,9 & 85,9 \\
\hline 2. & Cirebon Baru II & 92,0 & 85,9 \\
\hline 3. & Cirebon Baru III & 91,1 & 84,3 \\
\hline 4. & Cirebon Baru IV & 91,7 & 84,4 \\
\hline 5. & Temdak I & 91,2 & 86,0 \\
\hline 6. & Temdak II & 91,3 & 85,9 \\
\hline 7. & Kandang I & 91,4 & 85,7 \\
\hline 8. & Kandang II & 91,6 & 85,7 \\
\hline 9. & Kandang III & 91,7 & 85,5 \\
\hline
\end{tabular}

Dari tabel 1 dapat diketahui bahwa seluruh lingkungan kerja dengan posisi di bawah dekat mesin (titik 1) memiliki nilai intensitas kebisingan melampaui NAB. Sedangkan pada posisi atas dekat mesin (titik 2) terdapat 6 lokasi yang memiliki nilai intensitas kebisingan dibawah NAB.

Tabel 2

Gambaran Tekanan Darah Pekerja di Penggilingan Padi dan Kopi

\begin{tabular}{|l|l|l|l|l|}
\hline Tekanan Darah & Max & Min & SD & Mean \\
\hline Pekerja Bagian Bawah Dekat Mesin (Titik 1) & \multicolumn{1}{l|}{} \\
\hline Sistole Sebelum & 130 & 110 & 7.256 & 122.14 \\
\hline Sistole Sesudah & 140 & 120 & 6.289 & 128.93 \\
\hline Diastole Sebelum & 90 & 60 & 7.902 & 75.71 \\
\hline Diastole Sesudah & 90 & 70 & 7.164 & 80.71 \\
\hline Pekerja Bagian Atas Dekat Mesin (Titik 2) \\
\hline Sistole Sebelum & 120 & 110 & 5.940 & 123.39 \\
\hline Sistole Sesudah & 140 & 115 & 6.984 & 128.04 \\
\hline Diastole Sebelum & 90 & 60 & 8.381 & 79.64 \\
\hline Diastole Sesudah & 90 & 70 & 6.574 & 83.04 \\
\hline
\end{tabular}


Berdasarkan tabel 2 dapat diketahui bahwa nilai rata-rata untuk sistole setelah bekerja pada pekerja bagian bawah (titik 1) mengalami kenaikan lebih tinggi daripada pekerja bagian atas (titik 2) yakni $6.79 \mathrm{mmHg}$. Sedangkan nilai rata-rata untuk diastole setelah bekerja, pekerja bagian bawah (titik 1) juga mengalami kenaikan yang lebih tinggi dibandingkan dengan pekerja bagian atas (titik 2) yakni $5 \mathrm{mmHg}$.

Tabel 3

Gambaran Kenaikan Tekanan Darah Pekerja Penggilingan Padi dan Kopi

\begin{tabular}{|l|l|l|l|l|l|}
\hline \multirow{2}{*}{ Tekanan Darah } & Sistole & Diastole \\
\cline { 3 - 6 } & F & \% & F & \% \\
\hline \multirow{2}{*}{ Titik 1 } & Meningkat & 22 & 39.29 & 14 & 25 \\
\cline { 2 - 6 } & Tidak Meningkat & 6 & 10.71 & 14 & 25 \\
\hline \multirow{2}{*}{ Titik 2 } & Meningkat & 17 & 30.36 & 10 & 20 \\
\cline { 2 - 6 } & Tidak Meningkat & 11 & 19.64 & 18 & 30 \\
\hline Total & $\mathbf{5 6}$ & $\mathbf{1 0 0}$ & $\mathbf{5 6}$ & $\mathbf{1 0 0}$ \\
\hline
\end{tabular}

Berdasarkan tabel 3 dapat diketahui bahwa dari 56 pekerja di penggilingan padi dan kopi terdapat 22 pekerja pada bagian bawah (titik 1) mengalami kenaikan tekanan darah sistole (39.29\%) dan 17 pekerja pada bagian atas (titik 2) tidak mengalami kenaikan tekanan darah Sistole (30.36\%). Sedangkan untuk tekanan darah diastole, sebanyak 14 pekerja bagian bawah (titik 1) mengalami kenaikan tekanan darah diastole (25\%) dan 18 pekerja bagian atas (titik 2) tidak mengalami kenaikan tekanan darah diastole $(30 \%)$.

\section{Analisis Bivariat}

Tabel 4

Distribusi Responden Berdasarkan Kenaikan Tekanan Darah Pekerja Penggilingan Padi dan Kopi

\begin{tabular}{|c|c|c|c|c|c|c|c|}
\hline \multirow{2}{*}{\multicolumn{2}{|c|}{ Tekanan Darah }} & \multicolumn{3}{|c|}{ Sistole } & \multicolumn{3}{|c|}{ Diastole } \\
\hline & & $\mathbf{F}$ & $\%$ & P Value & $\mathbf{F}$ & $\%$ & P Value \\
\hline \multirow[b]{2}{*}{ Titik 1} & Meningkat & 22 & 39.29 & \multirow[b]{2}{*}{0.000} & 14 & 25 & \multirow[b]{2}{*}{0.000} \\
\hline & $\begin{array}{l}\text { Tidak } \\
\text { Meningkat }\end{array}$ & 6 & 10.71 & & 14 & 25 & \\
\hline \multirow[b]{2}{*}{ Titik 2} & Meningkat & 17 & 30.36 & \multirow[b]{2}{*}{0.000} & 10 & 20 & \multirow[b]{2}{*}{0.002} \\
\hline & $\begin{array}{l}\text { Tidak } \\
\text { Meningkat }\end{array}$ & 11 & 19.64 & & 18 & 30 & \\
\hline \multicolumn{2}{|l|}{ Total } & 56 & 100 & & 56 & 100 & \\
\hline
\end{tabular}

Berdasarkan tabel 4 dapat diketahui bahwa berdasarkan hasil uji statistik Wil Coxon Signed Ranks Test didapatkan nilai $\mathrm{p}=0.000<\alpha(0.05)$ untuk tekanan darah sistole pekerja titik $1, \mathrm{p}=0.000<\alpha(0.05)$ untuk tekanan darah sistole pekerja titik $2, \mathrm{p}$ $=0.000<\alpha(0.05)$ untuk tekanan darah diastole pekerja titik 2 , dan $p=0.002<\alpha(0.05)$ untuk tekanan darah diastole pekerja titik 2. Sehingga terdapat perbedaan yang bermakna antara tekanan darah pekerja sebelum dan sesudah pekerja terpajan kebisingan di penggilingan padi dan kopi Kabupaten Kepahiang. 


\section{PEMBAHASAN}

\section{Kebisingan}

Dari hasil pengukuran kebisingan di 22 lokasi penggilingan padi didapatkan intensitas kebisingan pada titik 1 yaitu antara 90,7 - 93,5 dB, sedangan pada titik 2 didapatkan intensitas kebisingan antara 83,6 - 86,2 dB. Dapat diketahui bahwa dari 22 lokasi terdapat 6 lokasi pada titik 2 yang berada di bawah nilai ambang batas (NAB) yakni pada lokasi Tertik II (84,5 dB), Tebat Monok II (84,6 dB), Tebat Monok IV (83,6 dB), Kampung Bogor II (84,6 dB), Cirebon Baru III (84,3 dB), dan Cirebon Baru IV $(84,4 \mathrm{~dB})$.

Berdasarkan kriteria yang telah ditetapkan melalui Peraturan Menteri Tenaga Kerja dan Transmigrasi Republik Indonesia Nomor PER.13/MEN/X/2011, Nilai Ambang Batas intensitas kebisingan untuk waktu pemajanan 8 jam per hari adalah 85 dB. Jadi dapat dikatakan bahwa intensitas kebisingan penggilingan padi dan kopi pada titik 1 sebanyak 22 lokasi (100\%) telah melampaui NAB yang diperbolehkan, sedangkan intensitas kebisingan penggilingan padi dan kopi pada titik 2 sebanyak 16 lokasi $(72,73 \%)$ telah melampaui NAB.

Intensitas kebisingan di titik 1 yang mencapai 93,5 dB menurut Peraturan Menteri Tenaga Kerja dan Transmigrasi RI Nomor PER.13/MEN/X/2011 hanya diperbolehkan untuk waktu pemajanan 2 jam saja. Sedangkan pada kenyataannya tenaga kerja di titik 1 bekerja lebih dari 2 jam.

\section{Peningkatan Tekanan Darah}

Terlihat bahwa hampir seluruh pekerja di bagian bawah dekat mesin (titik 1) mengalami kenaikan tekanan darah sistolik, demikian dengan pekerja di bagian atas dekat mesin (titik 2) yang sebagian besar pekerjanya mengalami kenaikan tekanan darah sistolik. Sejalan dengan penelitian yang dilakukan Eny Hastuti, dkk (2005) dengan judul "Faktor-Faktor Risiko Kenaikan Tekanan Darah Pada Pekerja Yang Terpajan Kebisingan di Bandara Ahmad Yani Semarang" maka diperoleh hasil pengukuran tekanan darah sebelum dan sesudah bekerja diketahui bahwa terdapat 33 responden $(55,0 \%)$ mengalami kenaikan tekanan darah sistolik, sedangkan 27 responden $(45,0 \%)$ tekanan darah sistoliknya turun atau tetap.

Kenaikan tekanan darah biasanya berjalan bersama-sama antara sistolik dan diastolic. Pengaturan tekanan tergantung pada kontrol dan penentu utamanya yaitu curah jantung dan resistensi perifer total. Kontrol curah jantung banyak bergantung pada pengaturan kecepatan denyut jantung dan volume sekuncup, sementara resistensi perifer total terutama dilakukan oleh derajat vasokonstriksi arterial. Kenaikan kecepatan denyut jantung akan berpengaruh langsung pada tekanan darah sistolik, sedangkan tekanan darah diastolic lebih banyak dipengaruhi oelh resistensi perifer total (Eny Hastuti, 2005).

Diketahui bahwa terdapat rata-rata kenaikan tekanan darah diastolik pekerja pada posisi bawah dekat mesin (titik 1) sebesar $5 \mathrm{mmHg}$ dan rata-rata kenaikan tekanan darah diastolik pekerja pada posisi atas dekat mesin (titik 2) sebesar 3,39 $\mathrm{mmHg}$. Sejalan dengan penelitian yang dilakukan Siswati, dkk (2017) dengan judul "Hubungan Pajanan Kebisingan dengan Tekanan Darah dan Denyut Nadi Pada Pekerja Industri Kemasan Semen" maka diperoleh hasil bahwa adapun peningkatan tekanan darah diastole pada pekerja bagian produksi di industry kemasan semen memiliki nilai ratarata peningkatan sebesar 5,86 mmHg. Terjadi peningkatan tekanan darah diastole pekerja sebelum dan sesudah bekerja. 


\section{Mekanisme Kebisingan Menyebabkan Kenaikan Tekanan Darah}

Getaran suara ditangkap oleh daun telinga yang diteruskan ke liang telinga dan mengenai membrane timpani sehingga membrane timpani bergetar (Andrina, 2003). Lalu di telinga tengah, gelombang getaran yang dihasilkan tadi diteruskan melewati tulang-tulang pendengaran sampai ke cairan di kanalis simi sirkularis, adanya ligament antar tulang mengamplifikasi getaran yang dihasilkan dari gendang telinga. Lalu di telinga bagian dalam merupakan tempat ujung-ujung saraf pendengaran yang akan menghantarkan rangsangan suara tersebut ke pusat pendengaran di otak manusia (Novi, 2004).

Kebisingan bisa direspon oleh otak yang merasakan pengalaman ini sebagai ancaman atau stress, yang kemudian berhubungan dengan pengeluaran hormone stress seperti epinephrine, norepinephrine dan kortisol (Eny, dkk, 2005). Hormon norepinephrine merupakan hormone vasokonstriktor yang sangat kuat yang dapat meningkatkan tahanan perifer total. Sedangkan kortisol menyebabkan peningkatan tekanan darah (Guyton dan Hall, 1997).

Pemaparan kebisingan menimbulkan rangsangan dan meningkatkan aktivitas saraf simpatis. Jika rangsangan tersebut bersifat sementara maka tubuh akan pulih dalam waktu beberapa menit atau jam. Tetapi bila pemaparan berlangsung lama dan berulang dapat menimbulkan perubahan sistem sirkulasi darah yang menetap. Saraf simpatis mempengaruhi fungsi jantung dan pembuluh darah dan pemacunya menyebabkan naiknya frekuensi jantung, bertambah kuatnya konstriksi otot jantung dan vasokontriksi pembuluh darah resisten (Guyton dan Hall, 1997).

Paparan kebisingan secara akut dan kronis merupakan faktor eksternal yang berpengaruh dalam meningkatkan denyut nadi dan tekanan darah (Kalantary dkk, 2015). Efek bahaya yang ditimbulkan akibat kebisingan tergantung pada besar intensitas, lama paparan dan frekuensi tinggi rendahnya suara (Aluko \& Nna, 2015). Besar-nya intensitas dan lamanya paparan kebisingan akan mempengaruhi respon tubuh terhadap kebisingan (Meena, 2011). Paparan kebisingan secara akut berhubungan dengan perubahan jangka pendek pada tekanan darah, denyut nadi serta peningkatan hormon stres sedangkan paparan kebisingan kronis dan jangka panjang akan meng-aktifasi sistem simpatis dan endokrin (Suchang Chen dkk, 2017).

Paparan kebisingan intensitas tinggi dapat direspon oleh tubuh sebagai respon stres. Menurut Babissch, dkk (2013), mekanisme respon stres akibat kebisingan yang dirasakan tubuh dapat terjadi melalui 2 jalur yaitu jalur langsung (direct pathway) dan jalur tidak langsung (indirect pathway). Direct pathway merupakan interaksi langsung antara sistem saraf auditory pusat dengan sistem saraf pusat (central nervous system/CNS). Direct pathway merupakan mekanisme yang sering terjadi saat seseorang tidur dalam kebisingan meskipun dengan tingkat kebisingan yang rendah (Basner dkk, 2014). Hal ini dikarenakan sistem pendengaran akan selalu aktif bahkan disaat tidur (Aluko \& Nna, 2015). Sedangkan indirect pathway merupakan reaksi emosional saat merasakan ketidaknyamanan akibat kebisingan (Babissch dkk, 2013).

Kebisingan level tinggi direspon oleh otak sebagai sinyal stress dan di-kirimkan ke amygdala. Amygdala me-nerjemahkan sinyal tersebut sebagai sinyal bahaya dan segera mengirimkan sinyal tersebut ke hipotalamus. Hipo-talamus menyampaikan ke sistem saraf otonom yang mengatur kardiovaskular, tekanan darah dan denyut nadi (Aluko \& Nna, 2015). Sistem saraf otonom terdiri dari sistem saraf simpatis dan sistem parasimpatis yang berfungsi untuk mengatur aktifitas fisiologis. Pada saat tubuh mengalami stres mental atau stres fisiologis, sistem saraf simpatis akan lebih aktif 
dibandingkan dengan sistem saraf parasimpatis (Recio dkk, 2016). Sistem saraf simpatis akan melepas epineprin dan norepineprin dari ujung saraf. Pelepasan epineprin dan norepineprin akan menyebabkan kenaik-an denyut jantung akibat meningkatnya kontraksi myocardial (Aluko \& Nna, 2015). Meningkatnya denyut jantung akan mengakibatkan perubahan tekanan darah (Siswati \& Adriyani, 2017). Meningkatnya kecepatan denyut jantung akan berpengaruh langsung pada te-kanan darah sistolik, tetapi butuh waktu untuk mempengaruhi tekanan darah diastolik. Hal ini yang menyebabkan kenaikan tekanan darah diastolik lebih kecil dibandingkan kenaikan tekanan darah sistolik. (Hastuti, Setiani, \& Nurjazuli, 2005 ; dalam Dwiyanti, E, 2018). Peningkatan ke-cepatan denyut jantung akan ber-pengaruh langsung pada tekanan darah sistolik, sedangkan tekanan darah diastolik lebih banyak di pengaruhi oleh resistensi perifer total (Huldani, 2012).

Sinyal aktivasi yang dikirim dari sistem saraf otonom dan sistem endokrin juga akan memicu medulla adrenal untuk melepas hormon katekolamin (Singhal dkk, 2009 ; Dwiyanti, E, 2018). Ketika dilepas, katekolamin meningkatkan kontraksi myocardial dan tekanan darah serta curah jantung (Liu dkk, 2016). Catecholamines merupakan hormon epinefrin dan norepinefrin (Aaronson dkk, 2010). Selain hormon catecholamines juga terdapat pening-katan hormon kortisol yang dikeluarkan akibat respon tubuh terhadap stres akibat kebisingan yang dapat meningkatkan denyut nadi dan rata-rata tekanan arteri (Souza, 2015). Peningkatan adrenalin akan menyebabkan konstriksi aliran darah arteri sehingga tekanan darah meningkat (Pangemanan, Engka, \& Kalesaran, 2012).

\section{SIMPULAN}

Berdasarkan penelitian dan pembahasan yang telah dilakukan mengenai perbedaan tekanan darah sebelum dan sesudah pekerja terpajan kebisingan di penggilingan padi dan kopi Kabupaten Kepahiang tahun 2017, maka dapat diambil kesimpulan sebagai berikut:

Dari 22 lokasi penggilingan padi dan kopi diketahui bahwa seluruh lingkungan kerja dengan posisi di bawah dekat mesin (titik 1) memiliki nilai intensitas kebisingan melampaui Nilai Ambang Batas $(>85 \mathrm{~dB})$. Sedangkan pada posisi atas dekat mesin (titik 2) terdapat 6 lokasi yang memiliki nilai intensitas kebisingan di bawah Nilai Ambang Batas $(\leq 85 \mathrm{~dB})$.

Dari 56 pekerja di penggilingan padi dan kopi terdapat 22 pekerja pada bagian bawah (titik 1) mengalami kenaikan tekanan darah sistole (39.29 \%) dan 17 pekerja pada bagian atas (titik 2) tidak mengalami kenaikan tekanan darah Sistole $(30.36 \%)$. Sedangkan untuk tekanan darah diastole, sebanyak 14 pekerja bagian bawah (titik 1) mengalami kenaikan tekanan darah diastole (25\%) dan 18 pekerja bagian atas (titik 2) tidak mengalami kenaikan tekanan darah diastole (30\%).

Berdasarkan hasil uji statistik Wil Coxon Signed Ranks Test terdapat perbedaan yang bermakna antara tekanan darah pekerja sebelum dan sesudah pekerja terpajan kebisingan di penggilingan padi dan kopi Kabupaten Kepahiang.

\section{SARAN}

\section{Untuk Pemilik Usaha dan Pekerja}

Sebaiknya pekerja menjaga waktu kontak pekerja dengan kebisingan, yaitu untuk titik pekerjaan yang mempunyai intensitas kebisingan sebesar $91 \mathrm{~dB}$, pekerja diperbolehkan berada di dekat mesin maksimal hanya 2 jam per hari. Sebaiknya pekerja 
diwajibkan untuk menggunakan alat pelindung telinga. Alat pelindung telinga berfungsi untuk menurunkan tingkat kebisingan yang mencapai alat pendengar. Alat pelindung telinga dapat berupa ear plug yang mampu menurunkan intensitas kebisingan 25-30 dB maupun ear muff yang dapat menurunkan intensitas kebisingan 30-40 dB. Sebaiknya pekerja melakukan pemeriksaan tekanan darah secara periodic untuk pemantauan kesehatan, terutama pada pekerja yang terpajan kebisingan melebihi ambang batas. Sebaiknya pekerja tidak melakukan kebiasaan merokok saat sedang bekerja. Selain it u, akan lebih baik jika pekerja berhenti merokok.

\section{Untuk Peneliti Selanjutnya}

Untuk penelitian selanjutnya disarankan untuk dapat mengikutsertakan variabelvariabel lainnya yang berhubungan dengan kebisingan dan kenaikan tekanan darah. Selain itu menggunakan alat ukur yang lebih baik, seperti Sound Level Meter yang mempunyai Leq atau menggunakan noise meter untuk mengukur kebisingan, untuk pengukuran tekanan darah sebaiknya menggunakan sfignomanometer air raksa. Untuk peneliti selanjutnya disarankan agar dapat dapat mengukur tekanan darah setelah pekerja istirahat untuk mengetahui apakah tekanan darah pekerja kembali turun atau tidak.

\section{DAFTAR PUSTAKA}

Aaronson, P.I., Ward, J.P.T. (2010). At a Glance Sistem Kardiovaskular. Jakarta: Erlangga

Aluko, E.O., \& Nna, V.U. (2015). Impact of Noise Pollution on Human Cardiovascular System. International Journal of Tropical Disease \& Health 6 (2): 35-43

Andri, J., Waluyo, A., Jumaiyah, W., \& Nastashia, D. (2018). Efektivitas Isometric Handgrip Exercise dan Slow Deep Breathing Exercise terhadap Perubahan Tekanan Darah pada Penderita Hipertensi. Jurnal Keperawatan Silampari, 2(1): 371-384. https://doi.org/https://doi.org/10.31539/jks.v2i1.382

Andrina Yunita. (2003). Gangguan Pendengaran Akibat Bising. Sumatera Utara: Fakultas Kedokteran USU

Babisch, W., Pershagen, G., Selander, J., Houthuijs, D., Breugelmans, O., Cadum, E., et al. (2013). Noise Annoyance-A Modifier of the Association Between Noise Level and Cardiovascular Health? Journal Science of the Total Environment, 5057.

Basner, M., Babisch, W., Davis, A., Brink, M., Clark, C., Janssen, S., et al. (2014). Auditory and Non-Auditory Effect of Noise on Health. NIH Public Accces, 118.

Budiono, A. M. S. (2003). Bunga Rampai Hiperkes dan Keselamatan Kerja. Semarang: Badan Penerbit Universitas Diponegoro

Departemen Kesehatan, RI. (2009). Kesehatan dan Keselamatan Kerja. Pusat Kesehatan Kerja

Dwiyanti, E., Marji., Fanani, E. (2018). Pengaruh Intensitas Kebisingan terhadap Tekanan Darah dan Denyut Nadi pada Mahasiswa Peserta Praktikum Pengelasan II di Universitas Negeri Malang. Preventia : The Indonesian Journal of Public Health. 3(1)

Eny Hastuti, Onny Setiani, Nurjazuli. (2005). Faktor-Faktor Resiko Kenaikan Tekanan Darah Pada Pekerja Yang Terpajan Kebisingan Di Bandara Ahmad Yani Semarang. JKLI, 4 (2) 
Foraster, M., Kunzli, n., Aguilera, I., Rivera, M., Agis, D., Vila, J. (2014). High Blood Presure and Long-Term Exposure to Indoor Noise and Air Pollution from Road Traffic. Journal Environmental Health Perspectives, 122 (11): 1193-1200

F.S,Gill.J.M,Harrington. (2003). Buku Saku Kesehatan Kerja Edisi ke 3. Jakarta:

Guyton, Hall. (1997). Buku Ajar Fisiologi Kedokteran. Jakarta: EGC

Huldani. (2012). Kebisingan Mempengaruhi Tekanan Darah Pekerja PT.PLN (Persero) sektor Barito PLTD Trisakti, Banjarmasin. Jurnal CDK-199 39 (11): 813-816.

Jenni, Babba. (2007). Hubungan Intensitas Kebisingan Lingkungan Kerja dengan Peningkatan Tekanan Darah (Pemeliharaan Pada Karyawan PT. Semen Tonasa di Kabupaten Pangkep Sulawesi Selatan. Universitas Diponegoro Semarang

Jumali, Sumadi, Andriani, S., Subhi, M., Suprijanto, D., Handayani, W. D. (2013). Prevalensi dan Faktor Risiko Tuli Akibat Bising pada Operator Mesin Kapal Feri. Kesmas, Jurnal Kesehatan Masyarakat 7 (12): 545-555.

Kalantary, S., Dehghani, A., Yekaninejad, M. S., Omidi, L., \& Rahimzadeh, M. (2015). The Effects of Occupational Noise on Blood

Liu J, Xu M, Ding L, Zhang H, Pan L, Liu Q. (2016). Prevalence of Hypertension and Noise - Induced Hearing Loss in Chinese Coal Miners. Journal of Thoracic Disease 8 (3): 422-429

Meena. (2011). The Study of the Effect of Sounds of Constant Frequency and Varying Intensity Levels on Systolic Blood Pressure, Diastolic Blood Pressure and Heart Rate of Healthy Individuals. Annals of Faculty Engineering HunedoraInternational Journal of Engineering 9 (3): 107-109.

Mortimer. (2011). Effect of short-term isometric handgrip training on blood pressure in middle-aged females, 22(5). Retrieved from www.cvja.co.za

NIOSH. (2015). NIOSH. Centers for Disease Control and Prevention (CDC) (online) http://www.cdc.gov/niosh/topics/noise/stats.html

Novi Arifiani. (2004). Pengaruh Kebisingan Terhadap Kesehatan Tenaga Kerja. Cermin Dunia Kedokteran No. 144

OSHA. (2016). OSHA. (online) https://www.osha.gov/SLTC/noisehearingconservation/index.html.

Pangemanan, D., Engka, J., \& Kalesaran, A. (2012). Pengaruh Pajanan Bising terhadap Pendengaran dan Tekanan Darah pada Pekerja Game Center di Kota Manado. Jurnal Biomedik, 4 (3): 133-140

Peraturan Menteri Tenaga Kerja dan Transmigrasi. (2011). Nilai Ambang Batas Faktor Fisika dan Faktor kimia di Tempat Kerja

Recio, A., Linares, C., Banegas, J. r., \& Diaz, J. (2016). Road Traffic Noise Effects on Cardiovascular, Respiratory, and Metabolic Health: An Integrative Model of Biological Mechanisms. Journal Environmental Research 146: 359-370.

Singhal, S., Yadaf, B., Hashmi, S., \& Muzammil, M. (2009). Effects of Workplace Noise on Blood Pressure and Heart Rate.

Siswati, \& Adriyani, R. (2017). Hubungan Pajanan Kebisingan dengan Tekanan Darah dan Denyut Nadi pada Pekerja Industri Kemasan Semen. Jurnal Kesehatan Lingkungan Indonesia, 16 (1): 29-36.

Souza, T. C., Perisse, A. R., \& Moura, M. (2015). Noise Exposure and Hypertension: Investigation of a Silent Relationship. Journal BioMed Central Public Health 15, (328): 1-9. 
Shuchang Chen, Yawin Ni, Lei Zhang, Liya Kong, Luying Lu, Zhangping Yang, et al. (2017). Noise Exposure in Occupational Setting Associated with Elevated Blood Pressure in China. Journal BMC Publich Health 17 (107): 1-7.

Zamanian, Z., Rostami, R., Hasanzadeh, J., \& Hashemi, H. (2013). Investigation of the Effect of Occupational Noise Exposure on Blood Pressure and Heart Rate of Steel Industry Workers. Journal of Environmental and Public Health: 1-3. 